Rudy Acuña. Mann, author of Taking on General Motors (1988), described the dramatic campaign to keep GM Van Nuys open; Acuña, Professor of Mexican American Studies (California State University, Northridge), stressed the role of minority workers and the black and brown Los Angeles communities in building a strong city-wide coalition, powerful enough to make the threat to boycott GM products in the huge Los Angeles auto market an effective bargaining ploy. Acuña stressed the role of Luis Olivares and other clergy in building community support.

With twenty workshops, three plenaries, and over eighty panelists and speakers, SWLSA ' 88 was one of the more successful of recent conferences. AFLClO state leader John Henning and Los Angeles Times labor editor Harry Bernstein both addressed plenary meetings.

A sampling of papers includes one on socialism in the 1910-11 San Diego elections by Leonard Pitt (CSU, Northridge); excerpts from a prize-winning book on minority labor struggles in the Pacific by Ed Beechert (Hawaii); a look at Harry Bridges's struggles with the law in San Francisco by Bob Cherny (CSU, San Francisco); and a report on the lives of working people of Philadelphia from 1750 to 1800 by Billie G. Smith (Montana).

This mixture of scholarly and activist reports is the hallmark of the SWLSA, which, from its beginning, has welcomed members, and drawn its leadership from both academia and the workplace. The 1988 meeting at Loyola Marymount drew close to four-hundred participants; fittingly, on the second day of the conference, two-hundred students from a community college program for working adults swelled the attendance. Professor Sally Miller (University of the Pacific) is SWLSA President. Frank Stricker (CSU, Dominguez Hills) chaired a very active conference committee.

\title{
Women, Work, and Family Life
}

\author{
Miriam Frank \\ New York University
}

The labor movement in the United States, during a decade when its membership has diminished drastically (currently 17 percent of U.S. workers are organized, down from 21 percent in 1978), has significantly shaped the debate on working women's issues. Indeed, one of the few bright spots in the entire trade union picture is the story of women's increasing membership ( 33 percent of union members in 1988 were female, up from 20 percent in 1973), especially in service-sector unions. On 30 April 1988, 125 trade unionists, labor educators, and academics attended the "Women, Work, and Family Life" Conference at the headquarters of the United Auto Workers in New York City. Focusing on organizing, parenting, wage 
discrimination, leadership, affirmative action, and the overall direction of public policy, the panels provoked lively discussions.

Veteran analyst Alice H. Cook (Cornell) surveyed the field of trade union feminism. She provided statistics on job segregation (82 percent of U.S. workers work primarily with members of their own sex), on part-time and temporary employment ( 90 percent female), and on the wage gaps between male and female and white and black workers. Her overview included both basic facts on women's union participation and leadership and suggestions on bargaining issues that would move union women. "The labor movement desperately needs coalition with women's groups," she urged. She also drew some valuable comparisons to family policies in Europe. When a baby is born in the U.S., the mother gets leave without pay; in Sweden both mothers and fathers get leaves - at 90 percent of their salaries.

Trade union feminism can be viewed in terms of the organizing and bargaining issues it has engendered. City University of New York sociologist Ruth Milkman noted that all the major comparable worth lawsuits have been filed by unions. Attorney Winn Newman later filled in this picture with a survey of recent payequity court cases, noting that often "the threat of litigation and legislation yields financial remedies in collective bargaining." Teamsters Organizing Director Vicki Saporta and District 65-UAW New York Regional Director Julie Kushner demonstrated that organizing campaigns are more successful at primarily female workplaces when organizers address questions of fairness or the quality of work along with wage inequities. For example, in hospital drives, nurses fight to improve staffing assignments; in offices, VDT equipment operators build their campaigns around health and safety; and at Columbia University's large clerical local, the exposure of racial discrimination continued to galvanize the union as it bargained its second contract.

The double burden of the working mother was an especially prominent topic throughout all the panels. Cook discussed the rigidity of the work day in terms of women's desires for scheduling flexibility, time off for family illnesses, and other "nonproductive" accommodations. Rutgers sociologist Heidi Hartmann's projections about the labor force of the twenty-first century included an analysis of corporations creating more part-time, temporary, and contingent positions. In some ways, this does accommodate family duties. However, she noted the trend for workers in full-time, full-benefit jobs to work more hours, while the new temporary and part-time workers are less secure and more economically vulnerable. "We're working harder and enjoying it less," she said. A progressive policy response would be to unionize in the part-time and temporary sectors, fighting for pay equity and job security; to get legislation on part-timers' fringe benefits; and to work towards a six-hour day for all workers. This would both reduce the part-time/ full-time differential and lay the basis for both parents to deal with family duties.

Another major theme of the conference was the development of women's trade union leadership. Milkman noted that as union membership shrinks, there are fewer top-office openings; only the death or retirement of a current leader provides 
vacancies that women might fill. Anna Padia, Human Rights Coordinator at the Newspaper Guild, noted that without a commitment from the center of the union bureaucracy, internal union affirmative action plans remain marginalized. Communications Workers of America representative Adrienne Taylor warned that leadership "power must be shared or the movement will lose its power altogether." Speaking from the floor, retired 1199 Vice President Al Evanoff criticized aging leaders whose holds on offices often stymie the development of new female leadership.

Economist Barbara Bergmann criticized bargaining strategies for pay equity and child care as being off the mark. She emphasized that the sex-segregated work force is the real root of the problem, arguing that until women push more deeply into nontraditional employment fields they can hold no real hopes of substantial wage gains. One union member remarked from the floor that little had been said at the conference about the women who work in manufacturing jobs. Indeed, the "good news" about women in the labor movement usually reports the great gains being made in organizing and bargaining in health services, the clerical trades, and the public sector. But as International Ladies' Garment Workers' Union Assistant Organizing Director Katie Quan demonstrated, women in the traditional manufacturing unions have developed some highly creative solutions to the double burden. In New York City's Chinatown, a concerted community/workplace drive among garment workers convinced the union to back a bilingual child care center. Funded jointly by the city and the employers, it has been serving seventy-five children since 1984 and has been a great organizing tool. Contrary to Bergmann's thesis that child care is a "fringe issue," Quan claims that it is critically important to working mothers, as important a benefit in bargaining as health care and pensions.

The conference covered the range of trade union women's issues and strategies in one day, and the expertise of the panelists provided several important focal points for thought. Only two weeks later, the Coalition for Labor Union Women gave us an opportunity to put into practice the issues discussed at the conference. The American Family Celebration in Washington, D.C., attracted thirty-five thousand union activists and their families to a sunny, speech-filled day at the Washington Monument. "Demand a new agenda for families"-child and elder care, economic security, family leaves - the posters proclaimed.

Clearly trade union feminism has found its main ideas and is mobilizing successfully. Women's numbers in the work force are increasing, and their organization is gaining strength. Only time will tell what the consequences will be. To what extent will working women substantially improve their situations through organizing and collective bargaining? And will trade union feminists be able to extend these gains to all working women through national legislation? 